\title{
KNG1 Gene Product
}

National Cancer Institute

\section{Source}

National Cancer Institute. KNG1 Gene Product. NCI Thesaurus. Code C136375.

A protein encoded by the KNG1 gene. 